\title{
BANKING CONCENTRATION IMPACT ON MARKET STRUCTURE OF POST-SOVIET AND EU MEMBER COUNTRY - ESTONIA
}

\author{
ILIA BOTSVADZE \\ $\mathrm{PhD}$ \\ International Black Sea University, Georgia \\ ibotsvadze@ibsu.edu.ge
}

\begin{abstract}
The new wave of mergers and acquisitions after the global financial crisis intensified the interest of policy makers and academics in bank concentration and competition and the role of the state in competition policies and regulations (policies and laws that affect the market structure and degree of competition). It is important to not only make sure that banking sector is competitive, transparent and efficient, but also stable. The purpose of the study was to investigate and analyze the degree of concentration in Estonian banking market and its impact on competition and market structure of financial markets over the period of 2013-2017. Both the structural and the non-structural measurement approaches of concentration and competition, along with the desk research, a case study and interviews with the financial sector professionals and an independent expert was employed to address research purpose. The findings of the study indicate that, in the Post-Soviet and nowadays EU member country - Estonia, high concentration coexist with the high and moderate competition levels and relationship between concentration and stability seems to be positive, meaning that high concentration results high stability of this banking market. The monopolistically competitive Baltic banking market is based on the contestable market equilibrium as banking sector is prone to the existence of high segmentation and product differentiation. Large banks with high share of foreign capital operate as universal banks, providing various services to the different market segments at very competitive rates, while smaller banks concentrate on a specific range of services. The Scandinavian-connected banking system of EU member Baltic country is modern and efficient, with best-regulation and high level of transparency in the region.

Estonian financial markets are bank dominated, characterized with monopolistic banking structure, with leading roles of a few universal profile banking institutions, dominating not only banking sector, but whole financial market.
\end{abstract}

\section{KEYWORDS: BANKING, COMPETITION, CONCENTRATION, FINANCIAL MARKET, STABILITY.}

For citation: Botsvadze I. (2020). Banking Concentration Impact on Market Structure of Post-Soviet and EU Member Country - Estonia. Globalization and Business, №9, pp. 77-85. https://doi.org/10.35945/gb.2020.09.009

\section{INTRODUCTION}

Both academics and policy makers perceive and underline the essence of a smoothly functioning financial system for an economy (Levine, 2004; Bodie \& Merton, 2005). The structure of the banking sector has long been a subject of policy interest centered mainly around a presumed tendency towards concentration and its effects upon competition, economic efficiency, bank profitability, financial and consequently macroeconomic stability.

The degree of banking market structure that shapes out competition and performance has been a "seriously debated topic". The global financial crisis intensified the interest of policy makers and academics in bank concentration and competition and the role of the state in competition policies and regulations (policies and laws that affect the market structure and degree of competition). Some argue that increases in competition and financial innovation in markets such as subprime lending produced the financial turmoil. Others worry that the crisis and government support of the largest (big) banks raised banking concentration, correspondingly reducing competition and access to finance, and conceivably contributing to future instability as a result of moral hazard problems associated with "too big to fail" institutions.

Competition in the banking system is desirable for efficiency, effectiveness and maximization of social welfare. Nonetheless, due to its significant roles and functions, there are some properties that distinguish banking from other industries. It is important to not only make sure that banking sector is competitive, transparent and efficient, but also stable.

The outcomes of plentiful researches have resulted in the existence of various bank concentration theories in the literature. These theories could be classified into pro concentration and cons concentration theories. 
The literature covering the relationship between the structure of the banking sector and level of competition and financial stability is classified according two separate views with absolutely contradictory conclusions. They are positioned according to either they back the theory that banking concentration has a destabilizing effect (concentrationfragility or competition- stability hypothesis) or either on the opposite it has a stabilizing effect (concentration-stability or competition-fragility hypothesis).

Concentration indicates the degree of control of economic activity by big companies (Sathye, 2002). The increase in concentration levels could be because of significant size enlargement of the dominant firm(s) and/ or significant size contraction of the non-dominant firm(s). Conversely, decrease in concentration levels could be because of significant size contraction of the dominant firm(s) and/ or significant size enlargement of the non-dominant firm(s) (Athanasoglou, Brissimis, \& Delis, 2005).

Supporters of banking sector concentration state that, enhancing of economies of scale is main trigger of realizing bank mergers and acquisitions resulting in increasing concentration. Such increased concentration promotes efficiency improvements (Demirguc-Kunt \& Levine, 2000). Based on theoretical assumptions and research results of country comparisons, low concentrated banking sector containing many small banks is deemed highly vulnerable to financial crises than highly concentrated banking sector with a several large banks. According to the "concentration-stability" and "competition-fragility" theory, high concentration in a banking sector lowers competition between banks and consequently decreases additional risktaking incentives of those institutions, resulting low risk of default and vice-versa. Besides, they argue that larger banks are having better diversification abilities, so banking markets composed by several large banks tend to be less fragile than banking markets with many small banks (Allen \& Gale, 2004).

Concentrated banking markets are mainly characterized by high profitability, which decreases fragility of the whole system. High profits act as a buffer mechanism toward adverse shocks and perils in difficult times. Besides, monitoring several large banks are easier, than many small banks and corporate control mechanism will be more effective of larger banks, resulting decreasing risks of contagion in a concentrated banking system (Beck, Demirguc-Kunt, \& Levine, 2003).

According to the opposite view, high concentration in banking market increases the prices of financial services for consumers. In concentrative and less competitive environment banks charge high interest rates on loans and low interest rate on deposits, maintaining high interest rate spreads and enjoying with high profits. Also, there is an evidence connecting high concentration to reductions of credit supply and access to finance for firms.

If concentration empowers banks with ability of influence on the market, such circumstances will have impact on riskiness of bank assets and will rise both the expected rate of return on assets and the standard deviation of those returns (Beck, Demirguc-Kunt, \& Levine, 2004). The rationalize of this connotation is that high power of influence of banks sourced by higher market concentration creates basis for low socioeconomic welfare and, consequently, high concentration is eminently undesirable. Aside, concentrated banking market rises bank fragility incentives, due to larger banks usually are granted by support subsidies from government, based on "too big to fail" policies that small banks do not receive (Boyd \& Runkle, 1993).

Supporters of the "concentration-fragility" view do not agree with the statement, that easier to monitor several large banks, than many small banks. As generally the size of such conglomerates is presented in complexity, monitoring and supervising of activities of large banks becomes much difficult than small banks. This type of relationship underlines and rises positive connection between concentration and fragility. Theoretical results highlight that financing activities of larger banks become more expensive due to their monopolistic market power increases the opportunity costs of capital (Smith, 1998). Thus, lack of proper competition in banking market negatively affects economic development.

There is a continuing dispute in academic literature on the relationships between competition, concentration and stability in the banking sector. According to the "concentration-stability" or "competition-fragility" theory, there is positive relationship between concentration and stability, but negative relationship between concentration and competition, and competition and stability. On the one hand, there are academics and policy makers who believe that more competition in banking results in greater instability and more market failures, other things being equal. This theory suggests that banks operating in a highly concentrated market (or in a market that restricts entry) will earn profits that can serve as a buffer against fragility, and as an incentive against excessive risk taking. More competition, which puts more pressure on profits, is thought to create higher incentives for banks to take greater (potentially excessive) risks, resulting in greater instability. This theory predicts that deregulation, resulting in more entry and competition, would ultimately lead to more fragility. It also holds that a more concentrated banking system might reduce the supervisory burden of regulators, thus enhancing overall stability.

The opposing view is that a more concentrated banking structure in fact results in more bank fragility, supported by concentration-fragility or competition-stability theory. According to this theory, there is negative relationship between concentration and competition and concentration and stability, but positive relationship between competition and stability. In such environment fragility of the market is increased due to banks power to boost the interest rates they charge to firms rising firms default riskiness connected to a higher probability of non-performing loans, which will result in expensive financial product and limited access to finance, consequently affecting economic processes. Besides, high concentration of larger firms is precondition for increased contagion or systematic risk. In the highly concentrated markets, huge conglomerates become very important for the sustainability of the market and is presumed that such banks will receive larger subsidies via "too big to fail" policies, thereby intensifying moral hazard problems by additional 
risk-taking incentives and consequently increasing banking system fragility. This intension destroys the argument of less need for supervision of big banks in a highly concentrated market with the evidence that highly concentrated banking systems with conglomerates offering a wide array of services, makes them more complicated and difficult to monitor. On the same line high level of competition makes banking institutions behavior more transparent and conventional with increased attention to the risk management, thus ensuring sustainability of the financial system.

As shown in the recent financial turmoil, regulation affects the resilience of financial institutions to a crisis. Countries with strong regulatory and institutional frameworks have been less prone to financial distress. A well-designed regulatory framework can also help reduce the potential detrimental effects of competition on financial stability in particular by improving banks' risk-taking incentives. In other words, regulation can make banks less inclined to take on excessive risk. At the same time, ensuring transparency and equally treatments of all participants will promote high performance of overall sector and economic development.

\section{Research Methodology and Data Analysis Instruments}

The research is empirical by nature and it shaped the logic and instruments through which objective and measurable data were collected and analyzed. Intensive and comprehensive review of existing theories enabled us to formulate research questions and hypothesis, define relevant data and the tools and methods for quantitative analysis. Positivist paradigm employed in the research implies the existence of reality independently from the researcher. Based on those assumptions, objective reality observable through secondary data about levels of concentration and market structure of post-Soviet countries banking sectors is estimated. Having shown a positivist epistemology of the research based on, what can also be referred to as scientific approach (Sekaran \& Bougie, 2016), we need to explain that the research is not purely quantitative, but employs qualitative research paradigm as well. Thus, through this perspective, the study follows pragmatism consideration and uses mixed methodology approach. The mixed methodology, or pragmatist approach, enabled the researcher, on the one hand to define the link between the variables through quantitative research, and on the other hand, qualitative approach gave an opportunity to study the research problem deeper and from different perspectives presenting views and interests of various stakeholders.

Considering research questions, the study utilizes quantitative and qualitative research methods. But research is mainly based on quantitative methods of analysis. Concentration ratios and Herfindahl - Hirschman index is employed to measure concentration levels. Panzar and Rosse's model is employed for measurements of competition. The "H-statistic" is computed on two stages. First stage includes, employing regression model based on of the logarithmic form of total revenues on logarithmic form measures of banks' input prices. Input prices consist of the price of deposits (commonly measured as the ratio of interest expenses to total deposits), the price of personnel (measured by the ratio of personnel expenses to assets), and the price of equipment and fixed capital (approximated by the ratio of other operating and administrative expenses to total assets). Second stage includes computation the sum of the estimated coefficients for each input price for drawing type and level of competition on the banking markets. The $Z$ score is used for measuring stability levels of banking markets. The $Z$ score envoys the number of standard deviations of return on assets the bank is away from bankruptcy, consequently a higher value of Z-score implies a higher banking stability. Besides, descriptive statistics and correlation analysis are used for assurance of data validation. Before conducting analysis of regression models, so called problem of multicollinearity was addressed and all independent variables with the correlation coefficients value within less than 0.8 are employed in the estimation of the regression model. The key assumption of the Panzar and Rosse's model, includes regressing the observations that are in long-run equilibrium, meaning that, the banking institutions under analysis are required to be operating in long-run equilibrium. For confirming this condition, a robustness test was carried out.

The qualitative study mainly includes desk research, case study and interviews with the financial sector professionals and independent experts for fulfilling the whole picture about the structure and levels of competition of banking sectors and draw precise recommendations.

Several variables will be researched using the secondary data. Such as: interest revenues, price of deposits (commonly measured as the ratio of interest expenses to total deposits), the price of personnel (as captured by the ratio of personnel expenses to assets), and the price of equipment and fixed capital (approximated by the ratio of other operating and administrative expenses to total assets), ROA, CAR.

\section{Results of Analysis Concentration Level in Estonian Banking Sector}

Estonian banking sector is comparably small, highly concentrated, with high share of foreign capital. Top 3 banks currently account for $79 \%$ of assets resulting with extremely high concentration. Swedbank with $41 \%$ of assets, Seb Bank with $24 \%$ of assets and Luminor Bank with $14 \%$ of assets are leaders of banking sector (Bank of Estonia, 2018). The leading largest banks are representing Scandinavian banking groups in form of affiliates and subsidiaries. In 2017, Nordea Bank AB Estonian branch was superseded by Luminor Bank, a joint venture of Nordea and DNB, resulting increasing concentration level even more (Nordea, 2018) (see. Figure 1).

The five largest banks control $92 \%$ of the market in Estonia. The influence of other banking institutions on the market is very low, which is confirmed by $\mathrm{HHI}$ index showing high level of banking concentration. Numbers of active banks are stable during 5 years, resulting steady $\mathrm{HHI}$ index with 2550 points at the end of 2017 (see. Table 1).

Large banks in Estonia operate as universal banks, 
Table 1. Concentration Level in Estonian Banking Sector

\begin{tabular}{|c|c|c|c|c|}
\hline Country-Estonia & $\mathrm{CR}_{3}$ & $\mathrm{CR}_{5}$ & HHI & Number of Banks \\
\hline $2013 y$ & $77 \%$ & $89 \%$ & 2513 & 15 \\
\hline $2014 y$ & $77 \%$ & $89 \%$ & 2488 & 15 \\
\hline $2015 y$ & $77 \%$ & $88 \%$ & 2406 & 16 \\
\hline $2016 y$ & $76 \%$ & $86 \%$ & 2368 & 16 \\
\hline $2017 y$ & $79 \%$ & $92 \%$ & 2550 & 17 \\
\hline
\end{tabular}

Source: Researcher's calculations

providing various services to the different market segments, while smaller banks concentrate on a specific range of services. Owning insurance, investment, brokerage and pension management firms, those conglomerates also enjoy dominant position in the rest of the financial sector. All those various types of services are offered to the customers through bank branches. In spite of extremely high concentration levels and existing of universal service providers, the supervisory authorities have not detected serious problems threatening to the competition in the banking and financial market (IMFEstonia, 2017).

The "Scandinavian-linked" banking market of Estonia is modern and efficient, including the strongest and bestregulated banking institutions in the region, providing a full range of financial, insurance, accounting and legal services to both domestic and international clients (including Internet and telephone banking) at very competitive rates. Estonia has a highly advanced Internet banking system, where 99\% of people use Internet banking services. The majority of Internet users make their daily transactions using Internet banking and smart-phone applications (PWC-Estonia, 2018).

\section{Competition on Estonian Banking Market}

According to the results of (Hausman, 1978) test by comparing the coefficients of fixed and random effects

\section{Banking Sector Assets 2017}

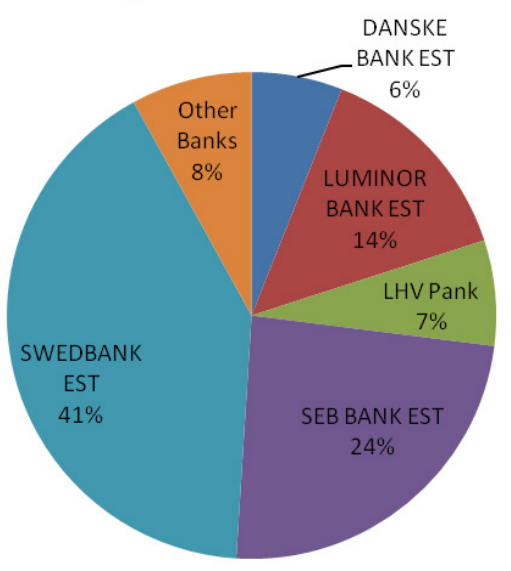

Figure 1. Asset Volume of Estonian Banking Sector

Source: Composed by Researcher; Bank of Estonia Statistics 2018 models, the random effects model was not rejected in favor of fixed effects, indicating that random effects model is appropriate in Estonian case.

The adjusted R-squared is having high value, accounting 0.80 , implying that, the independent variables in a high extent explain the dependent variable. The adjusted R-squared is reported instead of unadjusted one, due to the adjusted R-squared describes more precisely the picture of fit in case of the models consisting of many explanatory variables (Gujarati \& Porter, 2009).

The independent variables: price of funds (W1), the cost of labor (W2) and the cost of capital (W3) are positive determinants of the dependent variable, the total revenue. The price of funds or funding rate is not the highest contributing component in banks production functions like it was in case of previous three countries. Such outcome can be explained with the argument that, Estonia is a member of European Union and euro-zone, enjoying with low interest rates on both loans and deposits. In such situation interest income is not the factor that takes huge portion in generation of banks' revenues. The positive interconnection between interest expenses and revenues is sourced by borrowing and lending rates' coordinated movements, the same findings are highlighted by (Coccorese, 2009). Both variables, the cost of labor (W2) and the cost of capital (W3) are having positive values, which can be explained by the fact that, rising in costs of production increases the revenue, but till the point where marginal cost equals marginal revenue. Cost of labor with the coefficient of 0.50 is the variable contributing most to the $\mathrm{H}$ - statistic, meaning that costs related to the staffing decisions have quite high impact on revenue of Estonian banks as country operates advanced technologically banking system: the majority of the population conducts their daily transactions via internet banking and smart-phone applications. All variables $W 1, W 2$, and $W 3$ are statistically significant, meaning that they contribute to the H-statistic (see. Table 2).

The signs of the control variables are controversial. The equity to total assets, denoted as risk factor, has positive correlation with total revenue, which is not matched as anticipated, that lower capital ratio promotes the higher interest income. Such result can be based on fact that, top 5 banks controlling 92\% of the market in Estonia are representing Scandinavian banking groups in form of affiliates and subsidiaries. Such circumstances empower those banks with additional sources of capital, resulting 
Table 2. $\mathrm{H}$ statistics of Estonian Banking Sector

\begin{tabular}{|c|c|c|c|c|c|c|}
\hline \multicolumn{7}{|c|}{ Dependent Variable: LOG(TR/TA) } \\
\hline \multicolumn{3}{|c|}{ Panel Least Squares Pooled OLS } & \multicolumn{4}{|c|}{ Panel EGLS (Cross-section random effects) } \\
\hline Variable & $\begin{array}{c}\text { Coefficien } \\
t\end{array}$ & t-Statistic & Prob. & Coefficient & t-Statistic & Prob. \\
\hline C & -1.302746 & -2.261213 & 0.0296 & -1.153201 & -1.293389 & 0.2037 \\
\hline LOG (IntExp/TD) & 0.207917 & 2.798999 & 0.0080 & 0.192719 & 4.315698 & 0.0001 \\
\hline LOG (PersExp/TA) & 0.751952 & 6.068502 & 0.0000 & 0.496920 & 3.605155 & 0.0009 \\
\hline LOG (OthOperAdmExp/TA) & 0.256784 & 3.261051 & 0.0023 & 0.209317 & 2.873961 & 0.0066 \\
\hline LOG (TC/TA) & 0.110451 & 1.757908 & 0.0868 & 0.026592 & 0.620737 & 0.5385 \\
\hline LOG (NetLoans/TA) & -0.265758 & -3.983317 & 0.0003 & -0.198403 & -2.002980 & 0.0524 \\
\hline LOG(TA) & 0.186607 & 5.544576 & 0.0000 & 0.102526 & 1.779485 & 0.0832 \\
\hline H Statistics & \multicolumn{3}{|c|}{$\begin{array}{l}\text { Adjusted R-squared } \\
0.929608 \\
17+0.751952+0.256784=\mathbf{1 . 2 1 6 6} \\
\mathbf{5 3} \\
\mathrm{H}<1 \text {, monopolistic }\end{array}$} & \multicolumn{3}{|c|}{$\begin{array}{cr}\text { Adjusted R-squared } & 0.799901 \\
\mathrm{H}=0.192719+0.496920+0.209317=\mathbf{0 . 8 9 8 9 5 6} \\
0<\mathrm{H}<1, \text { monopolistic }\end{array}$} \\
\hline
\end{tabular}

Source: Researcher's calculations

minimization of risks. Finally, situation contributes positively to the revenue generation. The coefficient of net loans over total assets is anticipated to have positive sign, as expected more loans suggest more interest income, but it is negative with insignificant coefficient. Large banks in Estonia operate as universal banks, providing various services to the different market segments. Owning insurance, investment, brokerage and pension management firms, those conglomerates also enjoy dominant position in the rest of the financial sector, uncovers that income from loans are no more the bulky part of modern banks' income and biggest portion of the revenue now consists from other types of income. Total assets are positive contributor to total income as it represents source of potential future income.

The value of $\mathrm{H}$-statistic is 0.90 . According to the results of Wald test, the H-statistic coefficient is not equal zero or one, confirming that the banking sector is neither a monopoly nor perfectly competitive. Therefore, Estonian banking market is characterized by monopolistic competition. Obtained value of the $\mathrm{H}$-statistic is positive and significant, implying that banking institutions' revenues are derived in monopolistic competition environment of the Estonian banking sector. As competition coefficient is 0.9 , very close to 1 , then can be concluded, that banking institutions in Estonia are operating under monopolistic market structure with high level of competition.

\section{Stability in Estonian Banking Sector}

Table 3 represents results of $Z$ score of each individual banks and whole banking sector of Estonia. Two most stable banks are Seb Bank and Luminor Bank, the leading banks of the market, respectively with 193 and $90 \mathrm{Z}$ scores as an average for 5 years period. The leader bank of the market accounts quite moderate level of stability resulting average 35 score for five years. Rest of the banks can be characterized

Table 3. Z score of Estonian Banks

\begin{tabular}{|c|c|c|c|c|c|c|c|c|}
\hline $\mathbf{N}$ & Bank & $\begin{array}{c}\text { Z score } \\
2013\end{array}$ & $\begin{array}{c}\text { Z score } \\
2014\end{array}$ & $\begin{array}{c}\text { Z score } \\
2015\end{array}$ & $\begin{array}{c}\text { Z score } \\
2016\end{array}$ & $\begin{array}{c}\text { Z score } \\
2017\end{array}$ & $\begin{array}{c}\text { Bank } \\
\text { Average } \\
5 \text { year }\end{array}$ & $\begin{array}{c}\text { Forecasted } \\
\text { Z score } \\
2018\end{array}$ \\
\hline 1 & BIGBANK & 66.63 & 74.72 & 74.88 & 73.77 & 73.37 & 72.67 & 73.22 \\
\hline 2 & DANSKE & 14.88 & 10.48 & 63.28 & 91.25 & 14.53 & 38.88 & 14.88 \\
\hline 3 & LUMINOR BANK EST & 106.09 & 96.80 & 88.15 & 83.65 & 77.85 & 90.51 & 72.12 \\
\hline 4 & EKRE & 26.16 & 27.46 & 26.77 & 28.50 & 30.14 & 27.81 & 30.42 \\
\hline 5 & LHV Pank & 20.13 & 26.22 & 26.68 & 28.64 & 18.31 & 23.99 & 18.47 \\
\hline 6 & VERSOBANK & 17.31 & 13.03 & 13.71 & 22.50 & 15.08 & 16.33 & 17.08 \\
\hline 7 & SEB_PANK & 198.19 & 187.30 & 200.00 & 192.62 & 191.36 & 193.89 & 195.08 \\
\hline 8 & SWEDBANK EST & 42.09 & 42.38 & 30.30 & 31.84 & 32.08 & 35.74 & 30.89 \\
\hline \multirow[t]{2}{*}{9} & ÄRIP & 12.77 & 8.78 & 11.08 & 12.34 & 13.09 & 11.61 & 12.52 \\
\hline & Country Z score by year & 56.03 & 54.13 & 59.43 & 62.79 & 51.76 & 56.83 & 51.63 \\
\hline
\end{tabular}


with low stability levels ranging between 11 to 31 scores.

As Estonian banking market is dominated by foreignowned banks, the stability of country's banking system is connected to the soundness of Scandinavian banking groups. This fact is supported with $\mathrm{Z}$ score maintaining steady value during fiveyear period accounting 56 scores indicating high stability.

The banks operating in Estonian market are quite wellcapitalized, ensuring high protection of invested funds. High level foreign borrowing, generally from their parent institutions takes quite essential portion in Estonia's banks (IMF-Estonia, 2018). Those parent banking conglomerates do not hesitate in such supporting operations and their home supervisory authorities have also taken a supportive stance.

\section{CONCLUSION}

Banking Concentration Impact on Market Structure of Estonian Financial Market

The results show that Estonian banking market faces extremely high level of concentration with Top 3 leading bank controlling more than $79 \%$ of the market. The leading largest banks are representing Scandinavian banking groups in form of affiliates and subsidiaries. Swedbank with $41 \%$ of assets, Seb Bank with $24 \%$ of assets and Luminor Bank with $14 \%$ of assets are leaders of banking sector. The five largest banks control $92 \%$ of the market in Estonia. The influence of other banking institutions on the market is very low, which is confirmed by $\mathrm{HHI}$ index showing high level of banking concentration. Numbers of active banks are stable during 5 years, resulting steady $\mathrm{HHI}$ index with 2550 points at the end of 2017.

In contrast to the concentration, the banking sector in Estonia operates under monopolistic market structure with high level of competition. The competition measure accounts 0.90 , indicating that market is evolving toward perfect competition. Estonian banking institutions' revenues are derived under conditions of monopolistic competition, in such environment any new entry will lead to the "contestable markets equilibrium", where percentage increase of revenues will always be less than percentage increase in the input prices, as the demand for banking products facing individual banks is inelastic.

Large banks with high share of foreign capital operate as universal banks, providing various services to the different market segments, offering wide array of products to both local and foreign customers, while smaller banks concentrate on a specific range of services. That monopolistic competition is optimal for Estonian banking sector, as it encourages product differentiation on the market. Banks market differentiated products based on product quality and promotion strategies. However, close substitutability of the services reduces the level of monopolistic competition. Such environment makes banks able to generate more profits due to distinctive features of their services like brand, quality and advertising. The "Scandinavian-linked" banking market of Estonia is modern and efficient, including the strongest and best-regulated banking institutions in the region, providing a full range of financial, insurance, accounting and legal services to both domestic and international clients at very competitive rates. Entering Estonian economy in euro-zone initiated deregulation of interest rates. Since 2011 interest rates on loans and deposits as well spread between them have decreasing tendency (see. Figure 2). Very low deposit rates led many depositors to look for other options for deposits alongside the commercial banks and customers started to invest savings in capital market instruments and in other non-financial sectors assets. Such circumstances increased competition between bank and capital market players. The large banking groups do not rely only on deposits and attract funds through bonds (Bank of Estonia, 2017).

The Estonian financial sector is bank-focused. Banks are

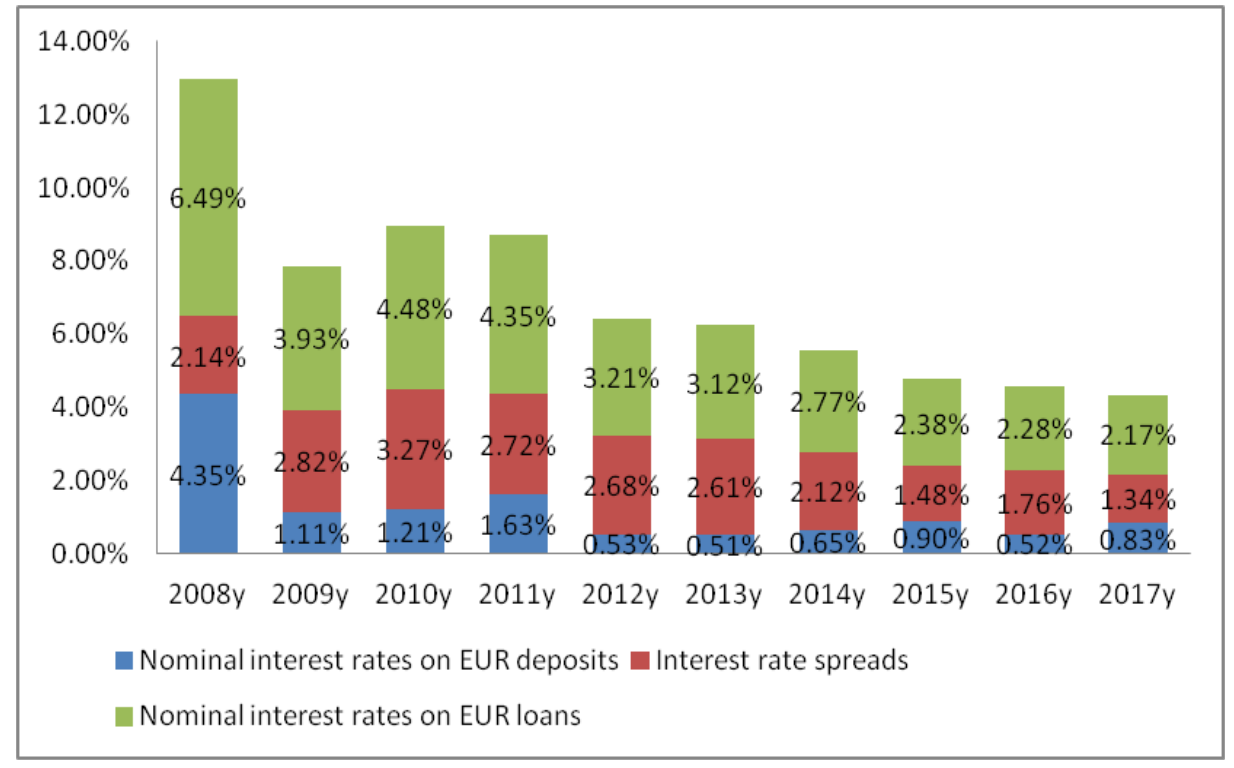

Figure 2. Interest Rates on EUR Loans and Deposits

Source: Composed by Researcher; Bank of Estonia Statistics 2018 


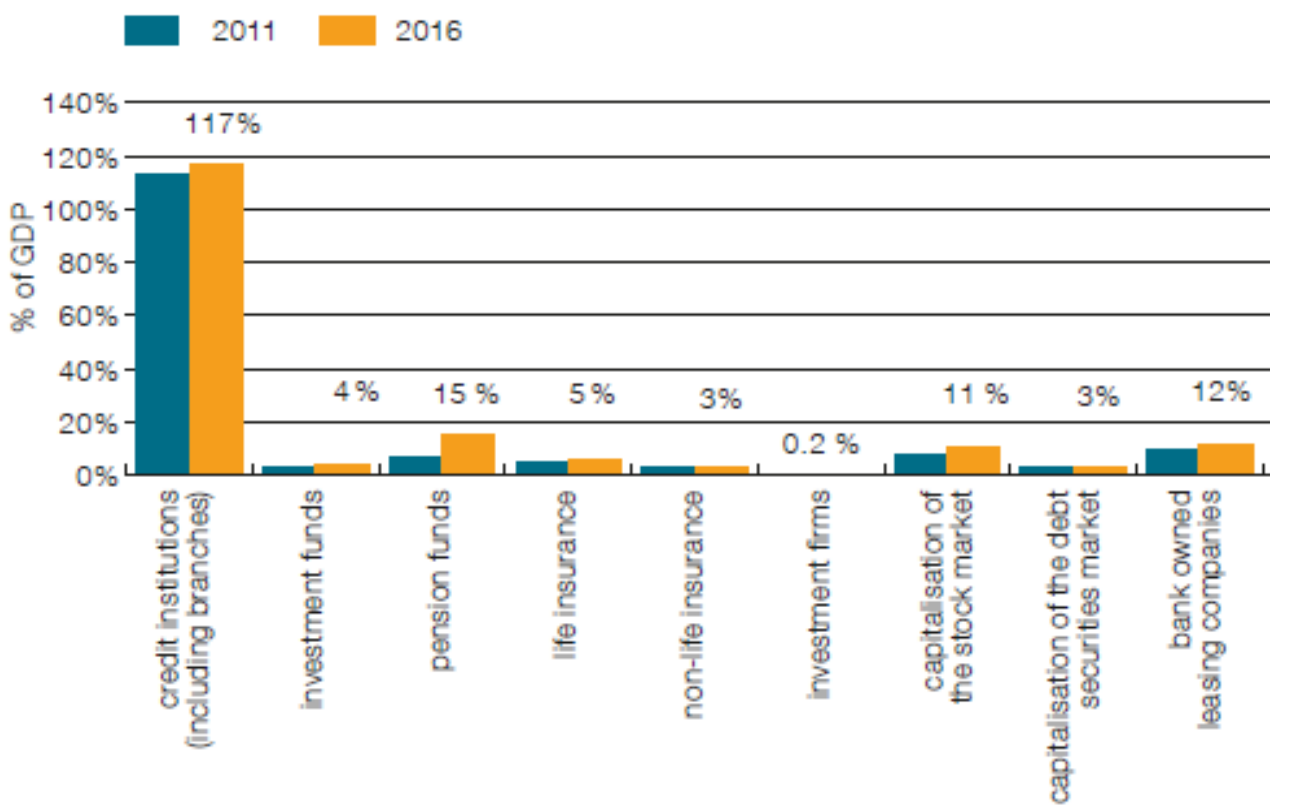

Figure 3. The Ratio of Assets of the Estonian Financial Sector to GDP Source: Bank of Estonia 2017

the largest part of the Estonian financial sector. There were 17 credit insti-tutions operating in Estonia at the end of 2017, seven of which were branches of foreign credit institutions. The banks had assets of 24.4 billion euro at the end of 2016, or $117 \%$ of GDP, which is below the average for the European Union (see. Figure 3). Besides, cross border banking services can also be provided in Estonia by more than 300 other financial institutions from the European Union (Bank of Estonia, 2017).

Capital market is quite developed and competes with banking market. The Estonian securities market is relatively small in size and in its number of issuers and it has

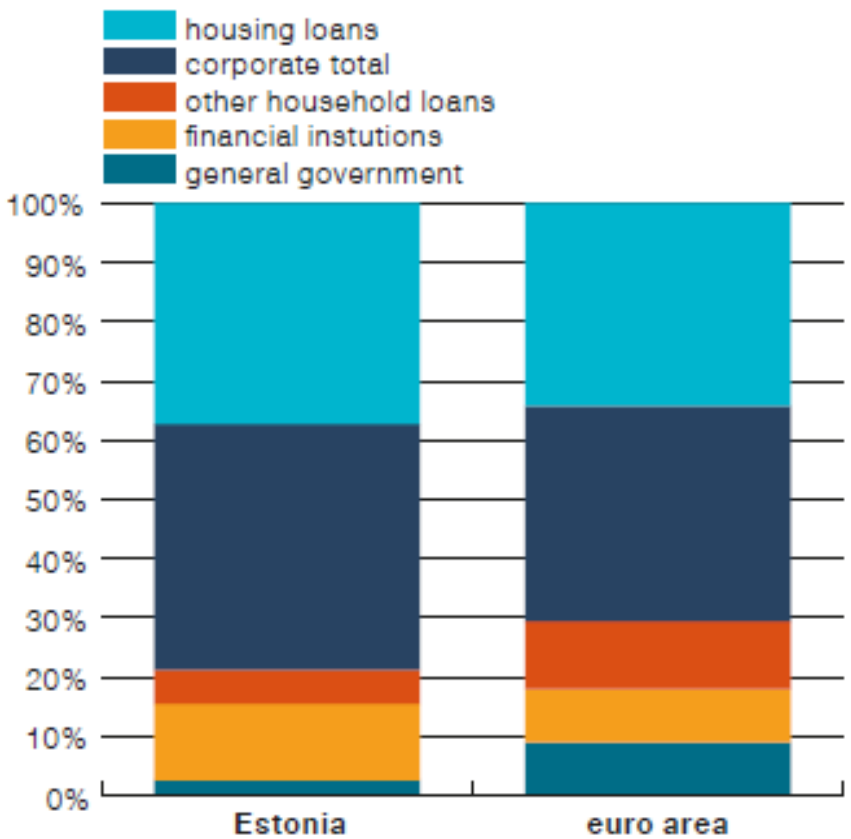

Figure 4. Loan Structure of Banks in Estonia and the Euro Area Source: Bank of Estonia 2017 only a limited impact on financial stability in Estonia. The capitalization of the stock exchange and the bond market stood at 3.5 billion euro or $15 \%$ of GDP at the end of January 2018, not comparable with banking $117 \%$. (Bank of Estonia, 2018).

Banks are main providers of funds to the businesses in Estonia. The division of the loan portfolio of the Estonian banks is affected by the funding structure of local companies and the general shape of the residential property market. Loans to companies comprise $42 \%$ of the portfolio and loans to households $43 \%$, while only $3 \%$ of the loans in the portfolio are to the general government and $12 \%$ to finance institutions. The share of loans to the general government is much smaller than the euro-area average because the state debt in Estonia is small. The share of corporate and housing loans is large though, as companies largely finance themselves through the banks and buying property is more popular than renting (Bank of Estonia, 2017) (see. Figure 4).

Estonian banks are intensive users of derivative financial instruments. The derivatives of the Estonian banks stood at 4.6 billion euro, or $20 \%$ of total assets, at the end of 2016 . Local banks use derivatives in their normal business activities mainly for managing interest and currency risks, with 52\% used for interest risks and 39\% for cur-rency risks (Bank of Estonia, 2017).

Access to finance in Estonia remains good, but the proportion of the SMEs seeking external financing is below the EU average. According to the World Bank/EBRD survey, the country is among the best performers in the EU on access to finance, with a steady improvement trend since 2008. Bank lending remains the main source of finance for SMEs in Estonia. Collateral requirements and guarantees are still considered a problem by smaller and newly created companies. Based on results, demand for credit of SMEs varies between 50 and $70 \%$, but had need for credit and was refused/discouraged from applying $20 \%$ of firms (see. Figure 
5). Estonian banks offering a full range of services without differentiation between local and foreign firms, increases the access to finance in Estonia as they do in Western European countries. Even though First North lets companies list their securities and so access capital cheaply with loose requirements, it is still relatively expensive for the smallest companies (OECD, 2017).

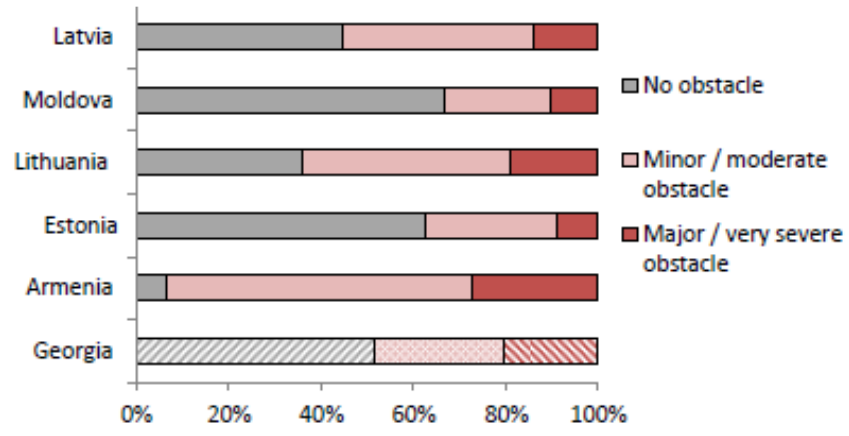

Figure 5. Access to Finance as an Obstacle for SME in Estonia Source: OECD, 2017

Situation and the structure of Estonian banking market is consistent with the "concentration-stability" view, stating that, concentrated banking markets may result in high profitability and therefore decrease potential bank fragility. High levels of revenues in line with profits will act as a buffer toward adverse shocks and increase sustainability level of the bank, reducing incentives for bank managers to take additional risk.

The profitability of the banks was a little lower in 2017 than a year before, but was still relatively good. The return on assets of the banks fell by the end of 2017 to $1.4 \%$. The return was affected most by dividend income and income tax expenses. Banks in Estonia between them earned more than 335 million euro in net profit in 2017 in total, which is 6\% less than a year earlier (see. Figure 6). The net profit of the banks has been affected greatly in recent years by the dividends received from subsidiaries and the cost of income tax paid. Without this, the profit of the banks would have been 5\% higher in 2017 than in the previous year (Bank of Estonia, 2018).

The bank power of influence, sourced from a concentrated banking market in Estonia, acts as comfort factor for shareholders and managers not to engage in highly risky operations and enables them for better customer selection, which strengthens and enhances the stability of the financial system. The creation of internationalized bank performing multiple activities based on diversification can promote financial stability, due to such banks are less sensitive to national economic conditions. Larger banks are having better diversification abilities, so banking markets composed by several large banks tend to be less fragile than banking markets with many small banks. Estonian banks owning insurance, investment, brokerage and pension management firms, also enjoy dominant position in the rest of the financial sector increasing the stability of whole market. Besides, a banking system presented with larger banking institutions could ease access to the information, reduce adverse selection and moral hazard problems. As an issue of competition, high-competitive and contestable financial markets promote innovations in finance and decrease the risk of regulatory capture, ensuring stability during normal times.

The stability measure of the Estonian banking sector seems to be on high level. As Estonian banking market

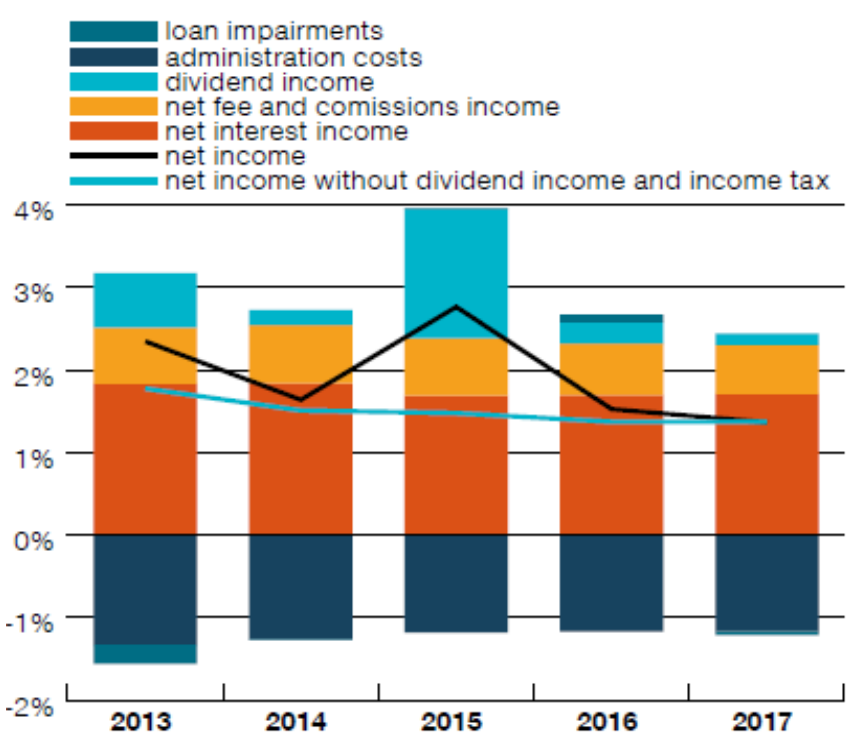

Figure 6. Profitability of Estonian Banking Sector Source: Bank of Estonia 2018

is dominated by foreign-owned banks, the stability of country's banking system is connected to the soundness of Scandinavian banking groups. This fact is supported with $\mathrm{Z}$ score maintaining steady value during five-year period accounting 56 scores indicating high stability. The banks operating in Estonian market are quite well-capitalized, ensuring high protection of invested funds. High level foreign borrowing, generally from their parent institutions takes quite essential portion in Estonia's banks (IMF-Estonia, 2018). Those parent banking conglomerates do not hesitate in such supporting operations and their home supervisory authorities have also taken a supportive stance.

In spite of extremely high concentration levels and existing of universal service providers, the supervisory authorities have not detected serious problems threatening to the competition in the banking and financial market. Estonia represents the model of banking market where under specific conditions high concentration can coexist with high competition, explained by the theory of contestability (Baumol, 1982). Proving that, high concentration is not itself dangerous under prudent regulation policy and does not excludes high competition in the market like in Estonian case.

Finally, Estonian banking system is characterized with high concentration level coexisting with high competition and resulting high market stability. The leading largest banks are representing Scandinavian banking groups in form of affiliates and subsidiaries. Monopolistic market structure of Estonian banks, with very low entry barriers and high segmentation promotes increase in credit supply and provides financial services with competitive prices under fair competition 
circumstances. Competition with capital market participants enables alternative sources of financing and increases access to finance of small firms. Large universal banking institutions under the Euro-standard regulation framework, with high share of foreign capital, owning insurance, investment, brokerage and pension management firms, also enjoy dominant position in the rest of the financial sector, thus ease access to the information, reduce adverse selection and moral hazard problems and increasing the stability of whole market. In spite of extremely high concentration levels and existing of universal service providers, the supervisory authorities have not detected serious problems threatening to the competition in the banking and financial market of Estonia.

\section{REFERENCES}

Allen, F., \& Gale, D. (2004). Competition and Financial Stability. Journal of Money, Credit, and Banking, Vol. 36(3), 453-480.

Athanasoglou, P., Brissimis, S., \& Delis, M. (2005). Bank-Specific, Industry-Specific and Macroeconomic Determinants of Bank Profitability. Bank of Greece Working Paper, No. 25.

Bank of Estonia. (2017, June). The Structure of The Estonian Financial Sector. Retrieved from Eesti Pank: https://www.eestipank. ee/sites/eestipank.ee/files/files/.../fsr 2017 eng_www.pdf

Bank of Estonia. (2018). Financial Stability Review I. Retrieved from Eesti Pank: https://www.eestipank.ee/en/publication/ financial-stability-review/2018/financial-stabilty-review-12018

Bank of Estonia. (2018, May). Statistics. Retrieved from Eesti Pank: http://statistika.eestipank.ee/\#/en/p/FINANTSSEKTOR/890

Baumol, W. J. (1982). Contestable markets: An uprising in the theory of industry structure. Americam Economic Review, $72,1-15$.

Beck, T., Demirguc-Kunt, A., \& Levine, R. (2003). Bank Concentration and Crises. NBER Working Paper No. 9921. Retrieved from http://www.nber.org/papers/W9921

Beck, T., Demirguc-Kunt, A., \& Levine, R. (2004). Bank Concentration and Fragility: Impact and Mechanics. Retrieved from http:// www.nber.org/books/risk/beck-et-al12-15-04.pdf

Bikker, J. A. (2004). Competition and Efficiency in a Unified European Banking Market. Cheltenham: Edward Elgar Publishing.

Bodie, Z., \& Merton, R. (2005). Design of financial systems: towards a synthesis of functions and structure. Journal of Investment Management, Vol. 3(1), 1-23.

Boyd, J., \& Runkle, D. (1993). Size and Performance of Banking Firms: Testing the Predictions of Theory. Journal of Monetary Economics(31), 47-67.

Coccorese, P. (2009). Market Power in Local Banking Monopolies. Journal of Banking and Finance, Vol. 33(7), 1196-1210.

Demirguc-Kunt, A., \& Levine, R. (2000). Bank Concentration: Cross Country Evidence. Retrieved from http://www.globalpolicy. org/socecon/tncs/mergers/imfbankcons.htm

Gujarati, D., \& Porter, D. (2009). Basic Econometrics (5th ed.). New York: McGraw Hill Inc.

Hausman, J. A. (1978). Specification tests in econometrics. Econometrica, Vol. 46(6), 1251-1271. doi:10.2307/1913827

IMF-Estonia. (2017). Republic of Estonia. Washington, D.C.: International Monetary Fund. Retrieved from https://www.imf.org/ en/Publications/CR/Issues/2017/01/13/Republic-of-Estonia-2016-Article-IV-Consultation-Press-Release-Staff-Report-andStatement-by-44524

IMF-Estonia. (2018). Republic of Estonia. Washington, D.C.: International Monetary Fund. Retrieved from https://www.imf. org/en/Publications/CR/Issues/2018/05/24/Republic-of-Estonia-2018-Article-IV-Consultation-Press-Release-and-StaffReport-45892

Levine, R. (2004). Finance and growth: theory and practice. NBER Working paper no. W10776. Retrieved from http://www.nber. org/books/risk/beck-et-al12-15-04.pdf

Matlack, C. (2015, May 8). Markets. Retrieved from Bloomberg: https://www.bloomberg.com/news/articles/2015-05-07/didthis-28-year-old-banker-help-steal-1-billion-from-moldova-

Molyneux, P., Lloyd-Williams, D. M., \& Thornton, J. (1994). Competitive conditions in european banking. Journal of Banking \& Finance, Vol.18(3), 445-459.

Nordea. (2018, May). Bank Category. Retrieved from TheBanks.eu: https://thebanks.eu/banks/13017

OECD. (2017, February). Enterprise performance and SME policies in the Eastern Partner countries and peer regions. Retrieved from OECD: https://www.oecd.org/eurasia/competitiveness-programme/eastern-partners/Enterprise-Performance-andSME-Policies-in-Eastern-Partner-Countries-and-Peer-Regions.pdf

PWC-Estonia. (2018). Doing business and investing in Estonia 2018. Retrieved from pwc: https://www.pwc.com/ee/et/ publications/DoingBusinessinEstonia/Doing\%20Business\%202018.pdf

Sathye, M. (2002). The Impact of Foreign Banks on Market Concentration: The Case of India. Applied Econometrics and International Development (AEEADE), Vol. 2(1), 7-20. Retrieved from http://www.ideas.repec.org/s/eaa/aeinde.html

Sekaran, U., \& Bougie, R. (2016). Research Methods for Business: A Skill-Building Approach (7th ed.). Chichester: John Wiley \& Sons.

Smith, R. T. (1998). Banking Competition and Macroeconomic Performance. Journal of Money, Credit and Banking, 30, $793-815$. 